Historic, Archive Document

Do not assume content reflects current scientific knowledge, policies, or practices. 


$$
\text { ' }
$$




\subsection{3}

\section{THOMPSON NURSERY}

J. M. Thompson E Son

PRuning, Planting LANDSCAPE WORK

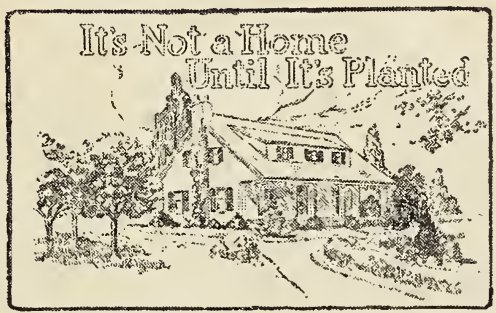

Plans and Estimates

Grounds: 2 Miles South 3rd and 4th Streets

Phone 2680 


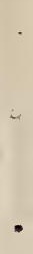




\section{Personal Greetings}

During our over thirty years of business at Waco, it has been our constant aim to furnish the best in our line, and have been at much pains and expense to secure and propagate the most successful varieties of all fruits and ornamentals suited to this climate. It is with real pleasure that we are able to make the statement that we do not believe there is a nursery in the South that can furnish a better list for our territory than we are offering this season. We have great numbers of satisfied customers of years standing, and we send out this season's catalogue feeling that we are in better position than ever to serve the tree planting public of the state. Our location enables us to reach all Texas in a very short time, and we guarantee stock to reach customers in good condition. We have a standing offer of more trees or your money back to anyone who feels that he has not had a fair deal. We also have membership in the American Association of Nurserymen, and this guarantees square dealing of all its members.

Counting on the continued patronage of our old customers and soliciting a trial order from those who have not dealt with us, we are yours for more and better orchards and more beautiful homes for Texas.

\section{BUSINESS NOTICES}

Unless instructed otherwise, we will fill orders with varieties nearest like those ordered, in case we are short of variety ordered.

Terms-Cash with order, or part cash if goods are to be shipped C. O. D.

Cost of Shipping-We pay express charges on all orders amounting to $\$ 5.00$ to any point in the state. This applies only to stock bought at printed prices unless by special arrangement, and cash must accompany order.

\section{Selecting Varieties}

If you are not sure just what varieties to plant, tell us the number of Peach, Plum, Roses, etc., that you want, conditions of soil, etc., and we will make a selection that we feel sure will please you.

\section{Our Responsibility}

We guarantee everything to be true to name and to reach purchaser in good condition, but our responsibility is in no case to exceed the cost of the trees. All stock bought must be accepted with this understanding. 


\section{Mistakes}

We are likely to make them, of course, but will gladly correct same if you will give us the opportunity. Write us promptly if there is anything you are not pleased with.

\section{Care of Trees on Arrival}

Be careful in unpacking to note everything and immediately "'heel-in"' in moist soil till planted, or plant at once. Never allow roots to dry. Plant an inch or two deeper than they grew in nursery, and be sure to cultivate thoroughly throughout the season.

When roses are budded, which can be told by examining the stem of the plant, they should be planted so that the knot made by the union of bud with stock will be at least two inches under the ground.

To plant fruit trees, throw in or take out soil until the tree stands the same depth as it did at the nur. sery; then throw in soil until the roots are covered, and pour in a bucket or more of water, shaking the tree; then fill in the balance of soil, mounding it up slightly, but do not pack. Then cut the top off from 12 to 24 inches from the ground. Some two-year-old trees should be cut above three or four of the branches and the branches cut three or four inches from the body.

By cutting all trees severely one almost insures the life of the tree, and it makes a low, robust, roundheaded tree that shades its own body. It is better to buy a tree and cut the top than to have it given to you and leave the top on.

If any limbs or roots of trees or plants are bruised or injured in any way, cut off all such injured parts.

Keep all sprouts or suckers cut off from 12 to 15 inches from the ground. At the end of the first year cut out the drooping and weaker branches of all trees. Pear and plums need the long branches cut back half the length or more, and this treatment may be given each year in January and February. In taking off a branch cut or saw close to the body of the tree.

Frequent and thorough cultivation with plow and hoe, especially for the first few years, is absolutely necessary.

To prevent rabbits from injuring young trees, we would suggest that either straw or cornstalks be tied around each tree. Old newspapers will answer the purpose, and either may be left on during the summer to partially shade the trunks of the trees. This is the only absolutely safe way to protect trees from these pests.

Never allow any stock to run in orchard.

Trees and plants, as a rule, should not be watered more than once a week in dry weather.

\section{PECANS}

Pecans are commonly considered hard to transplant. We find the difficulty is slight, if the tops are cut back, leaving only three or four eyes or buds above the point of the bud or graft, which can be told by a siight offset on the body of the tree. Plant trees two to four inches deeper than they stood in the nursery, according to size of trees, which are usually one to six feet tall. Dig holes at least two feet square and deep, and then put down a post hole in center of large hole one to two feet deeper, or as deep as may be necessary to hold the long root.

After trees are set and well watered, mound dry soil up on stem of tree a foot or more above level of 
ground, or even to top of the stem or trunk, after it has been cut back, as directed above. Leave a ditch around this mound to hold sufficient water to soak down to end of root. New growth will come through the mound of soil in the spring or summer, and the soil will work down gradually to a level.

\section{PERSIMMONS}

These should be cut back as directed for pecans, leaving about three good eyes or buds, above the graft. Plant trees slightly deeper than they stood in nursery, and mound soil upon stem, the same as for pecans.

\section{CONTROL OF INSECTS AND FUNGI}

For more detailed information, write A. \& M. College, College Station or State Department of Agriculture, Austin.

\section{Borers}

Borers are small white worms that work under the bark of trees.

To Prevent Borers-Rrake away earth around base of tree, and apply compound made of the following: Two quarts of strong soap, half pint of crude carbolic acid, with two ounces of Paris Green, thoroughly mixed in bucket of water, with enough lime and clay added to make a thin paste. Apply with paint brush.

To Destroy Borers. ... Most effective manner is to dig them out with sharp knife. They can be detected by swollen bark or oozing out of wax, and are always barely under bark of tree.

2. Inject small amount of high life (bi-sulphide of carbon) in holes or tunnels of borers, and stop up holes with clay, putty or wax.

\section{CUTTING ANTS}

(a) Place powdered cyanide of potassium around every hole.

(b) Dig into holes and place a cob or rag saturated with high life (bi-sulphide of carbon) covering with soil and packing tight. Be sure to find all beds or holes. Two or three applications may be necessary to get new beds that will be started. Be careful not to set the liquid on fire, or let it touch the skin, or the fumes reach the nose or eyes.

\section{FOR SUCKING INSECTS}

San Jose and other Plant Lice, Squash Bugs, etc.

\section{Kerosene Emulsion}

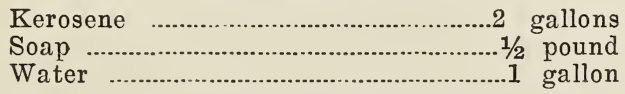

Dissolve soap in water by boiling, remove from fire, add kerosene, mix vigorously until all forms a creamy mass and emulsion. Dilute in from 10 to 35 gallons of water, according to tenderness of growth.

2. Lime-Sulphur Wash

For Dormant Trees Only

Stone lime .20 pounds

Sulphur 15 pounds

Water 50 gallons

Two iron kettles, each holding 20 to 25 gallons of water are necessary. Make sulphur into past by 
stirring in water, and add to about 115 gallons hot water in kettle No. 1.

Fill kettle No. 2, and boil water. When sulphur solution is boiling, gradually add stone lime. To prevent mixture from boiling over, pour small quantity of water from kettle No. 2 into it.

Boil about one hour, strain mixture into spray barrel, and add enough hot water to make 50 gallons. Spray in trees while mixture is hot, through coarse nozzle. After day's work, thoroughly clean spray machine with hot water.

\section{Sulphur}

Sprinkle plants with water, or, when dew is on, scatter sulphur over plants or spray through bellows. This is especially good for plant mites, such as red spider and rose aphis and rose mildew fungus.

\section{Potassium Sulphide}

Two ounces to gallon of water. Spray before mildew appears.

\section{DISTANCES FOR PLANTING}

Apples 20 to 25 feet apart each way Pears 20 to 25 feet apart each way Peaches, Plums, Apricots....16 to 20 feet apart each way Blackberries and Dewberries..2 to $3 \times 6 \mathrm{ft}$ apart each way Strawberries $2 \times 2$ or $1 \frac{1}{2} \times 3$ feet a part each way.

\section{NUIMBER OF TREES OR PLANTS TO THE ACRE}

1 foot apart each way

2 feet apart each way

43,560 plants

4 feet apart each way

6 feet apart each way

8 feet apart each way

10 feet apart each way

12 feet apart each way

14 feet apart each way

16 feet apart each way 10,800 plants

18 feet apart each way

20 feet apart each way

25 feet apart each way

30 feet apart each way

2,722 plants

1,210 plants

680 plants

435 plants

320 plants

223 plants

170 plants

130 plants

108 plants

69 plants

48 plants

We will make very close rates to Civic Improvement Clubs, Cemetery Associations or large planters. We think we can make it pay you to correspond with us. Write for special prices on 500 to 1000, or more, of anything quoted.

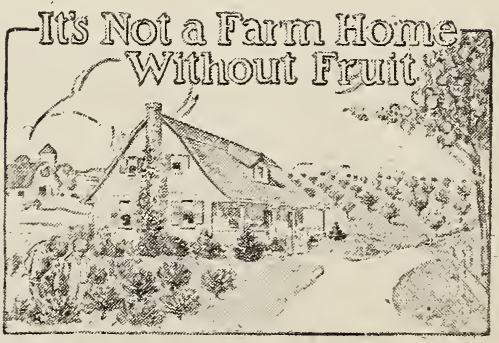




\section{Fruit Department}

\section{PEACHES}

The Peach is the leading fruit of the South, as the Apple is of the North and every home can easily have an abundant supply with very little effort or expense. Plant a peach wherever you have ten feet of space, and have an abundance of the finest fruit in the world.

Mayflower-Solid red, sure bearer, earliest grown.

Victor-White with red cheek; second early, best of its time.

Alexancier-Nearly covered with red; good quality; last of May.

Mamie Ross-Large White, very fine; early June. Carman-Like Mamie Ross, but a little later; very fine.

Alton-Large White, semi-cling. Great favorite in West.

Arp Beauty-Free, like Elberta. July 1st.

Hobson-Large white eling stone. Extra fine. July.

Pallas-White, free, medium size. Very sweet. Fine for southern part of state.

Honey-Similar to above.

Chinese Cling-Old favorite. Middle of July.

R. E. LeLe-Seedling of Chinese Cling and like parent, but better bearer.

Elberta-Large yellow, free. July 20th.

Leona-Like Elberta, but claimed to be better.

Belle of Georgia-Very fine, white, freestone. One of the best. July.

Minnie Stanford-Like Elberta, but clingstone.

Mixon Cling-White cling of highest quality; heavy bearer. August 10th.

Augbert, or August Elberta. Middle of August.

Red Indian-Real Indian peach. August.

Squaw-Indian freestone. August.

Salway-Yellow freestone. Latter part of August.

White Health-White Cling. September.

Stinson's October-White Cling. Sure and heavy bearer. October.

Bells October-Yellow Freestone. October.

\section{Prices}

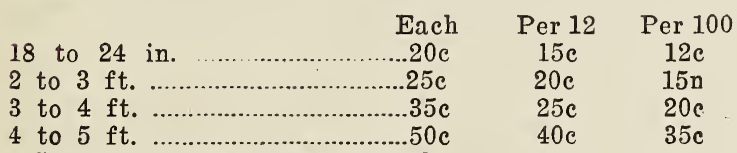

Large Trees, 5c to $\$ 1.00$ each.

\section{SPECIAL PEACHES}

Chas. Evans-A very fine yellow cling ripening in early August, after Elbertas are gone. Quality very fine, and a splendid keeper. Very fine home or market peach. 1 year trees $40 \mathrm{c}$. 2 year, $\$ 100$.

Finley Cling - A very large white cling of Chinese type, but covered with red and a fine bearer. Quality very fine. Originated at Waco on the old Finley home on South Fourth Street. We have never seen a cling peach we considered quite as good. About August 1st. 1 year trees $40 \mathrm{c}$; 2 year $\$ 1.00$.

Elizabeth Tanner-A very unusual peach, being a very large white freestone, much larger than Elberta.

$\checkmark$ Of splendid quality and ripening about the middle of August. It was found growing in the yard of $\mathrm{Mr}$. J. W. N. Tanner, in the north part of the city and 
is named for his daughter, Miss Elizabeth. 1 year trees $40 \mathrm{c} ; 2$ year $\$ 1.00$.

Chas. Beatty-Mr. Clias. Beatty, who is a veteran fruit grower, called our attention to a ycllow cling peach in his yard and said we could bud some trees from it. Te found it to be a real Jumbo and of fino quality. About August 1st. 1 year trees $40 \mathrm{c}$; 2 year trees $\$ 1.00$.

Dolly Sharp-A large to very large white cling peach found growing on the farm of Mir. W. T. Sharp of Riesel, Texas. The tree was quite old and widely known in that section. No other peach in that part of the country would compare with it in size and quality. It belongs to the Chinese type, a companion peacll for Finley Cling. Is named for Mr. Sharp.

The above Peaches we believe will easily rank with the best produced in the entire Peach world. For this section they are unsurpassed. 1 year trees $40 \mathrm{c} ; 2$ year trees $\$ 1.00$.

Japan Dream-This is a real dwarf tree, bearing very early, often fruiting in nursery row. Fruit about like Alexander in size, red with red meat like an Indian variety; heavy bearer. 1 year trees $40 \mathrm{c}$.

Yellow Swan-The earliest yellow peach. Large size yellow, covered with red; fine quality, good bearer. About June 1st. 1 year trees $40 \mathrm{c}$.

Harry Caldwell-Very fine white cling. July. 1 year trees $40 \mathrm{c}$.

Montopolis-Very fine large white cling, nearly covcred with red. Originated near Austin. August. 1-yr. trees $40 \mathrm{c}$.

Frand-White free. One of the Steubenrauch peaches. 1 year $40 \mathrm{c}$.

\section{PIUMS}

Plums are among our best and surest fruits and are fine for home and market. Most of the varieties ripen in June and July. Cultivate and keep borers out of bodies is main care required. The following list corers most of the best varieties.

Six Weeks-Large solid red. Ripe in May. Fine for market.

McCartney-Very early yellow; very sweet. Best in West.

Happiness-June. Japanese; fine quality. Should be gathered before soft.

Gonzales-Cross with Japan and Chicksaw. Fine quality, heavy bearer.

A.bundance-Japanese. Extra quality, good bearer.

Burbank-True Japanese. Splendid bearer; about July-1st.

America-Yellow with red cheek. Heavy bearer; verv fine.

Wild Goose-Last of June. Old standard variety; verv nopular; June.

Eagle-Very prolific. Long period of ripening. Chickasaw type.

Shiro-Large yellow. Fine quality.

Red June-Solid red. Heavy bearer. Japanese sort.

Nona-Cross of Wild Goose and Japanese. Fine variety.

Pool's Pride-Wild Goose type. Fine variety,

Heavy bearer.

Excelsior-Purplish red. Fine for South Texas.

Gold-Very fine yellow. July.

Wickson-Very large, egg-shaped. Yellow; fine quality.

Golden Beauty-Very late: heavy bearer. 


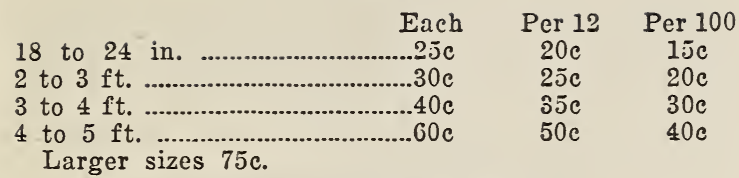

\section{COMPASS CHERRY PIUMS}

This is a cross between a cherry and a plum and is really a good substitute for cherries. Heavy and early bearer. Same price as plum.

\section{APRICOTS}

Early Golden, Cluster, Moorpark

These are about the best varieties for Texas.

2 to $3 \mathrm{ft}$. $35 \mathrm{c} ; 3$ to $4 \mathrm{ft}$. $50 \mathrm{c} ; 4$ to $5 \mathrm{ft} .75 \mathrm{c}$

\section{NECTARINE}

Like a peach, but smooth like a plum. Large red. $30 \mathrm{c}$ and $50 \mathrm{c}$

\section{PEARS}

The Pear is a very fine ornamental and fruit tree combined. Is fine for back and side yards. Also a fine market fruit and lasts fifty years or more.

Keiffer is still the most successful variety, being practically free from blight. Very large, jellow with red cheek. Ripens September and October.

Garber-Much like Keiffer, but ripens earlier and is of better quality. Ripens a month or more earlier.

Leconte-Medium size, greenish yellow and of good quality. Becomes almost nellow enough to eat on the tree. Ripens July.

\section{Prices}

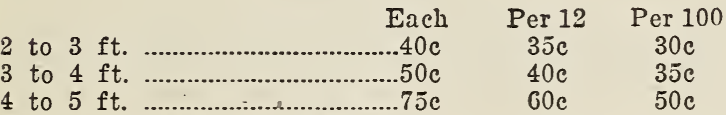

Large trees $\$ 1.00$ and $\$ 1.50$.

Ruby Wells-Special-This is a variety discovered here at Waco that gets mellow on the tree. Similar to Leconte in appearance.

Small trees 50c. Large size $\$ 1.00$ and $\$ 1.50$.

\section{APPLES}

This section of Texas is not considered an Apple country, but if trees are kept free from borers you will be surprised to see what Apples can be grown.

Red June-Medium size, solid red. Good quality.

Early Harvest-Medium to large, clear yellow. Ripens in June.

Arkansas Black-Large dark red. Fine quality. One of the best Fall Apples.

Ben Davis-Old standard variety. Red striped, sue cessful; October.

Jonathan-Solid red, fine quality; very popular; ripens August.

Texas Red-A very fine Texas variety. Solid red. Best Fall Apple.

\section{Prices}

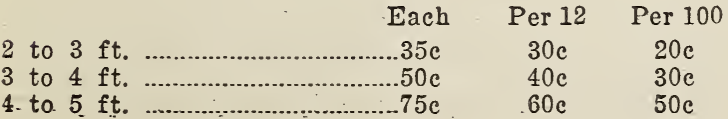




\section{SPECIAL APPLES}

Chester Davis-A new Apple originated in South Texas. A very early bearer and fine quality. Strong trees $\$ 1.00$. Only a few trees this season.

Crab Apples

Crab Apples are fine for cooking and are planted a great deal for ornamentals.

Transcendent-Prices $50 \mathrm{c}$ and $75 \mathrm{c}$.

CHERRIES

$75 \mathrm{c}$ and $\$ 1.00$.

El Richmond and Montmorency-Two of the very best for the South.

\section{QUINCE}

$50 \mathrm{c}$ and $75 \mathrm{c}$ Each.

\section{FIGS}

Small size 25c; Medium 50c; Extra size $75 \mathrm{c}$ and $\$ 1$

Celestial-The little blue Fig, sometimes called sugar fig. Very hardy.

Brown Turkey-Somewhat like above, but some larger and a little more brownish in color. Hardy and fine.

Green Ischia-Yellowish green in color, good size, delicate thin skin, pulp bright red. Very prolific.

Magnolia-Large, greenish color, brown at end. The great preserving fig of Southern Texas.

These are all successful in this section. Write for special rates on 100 lots or over.

\section{JAPAN PERSIMMON}

2 to $3 \mathrm{ft} .50 \mathrm{c} ; \quad 3$ to $4 \mathrm{ft} .75 \mathrm{c} ; \quad 4$ to $6 \mathrm{ft}$. $\$ 1.00$

The best yellow and dark fleshed varieties. Write for prices on 100 lots.

\section{MULBERRY}

\section{4 to $6 \mathrm{ft} .50 \mathrm{c} ; \quad 6$ to $8 \mathrm{ft} .75 \mathrm{c}$.}

Hicks Everbearing-The standard fruiting Mulberry. New American-New everbearing variety.

\section{GRAPES}

Grapes will grow almost anywhere that any other fruit can be grown, and deserve a much larger planting.

Concord-Old standard; large black. Last of June.

Niagara-Large greenish white, very fine. Early July.

Carman-Considered now the great commercial grape of Texas. Large bunch berry, little smaller than Concord. Very fine.

Moore's Diamond-One of the finest White Grapes known. Large bunch and berry. July.

Deleware-Highest quality, small grape and bunch. Red.

Catawba-Large red; old standard. Last of July.

Herbemont-Large bunch, small berry: Very fine grower and bearer. Very juicy.

1 year vines 25c; 2 year heavy bearing size $50 \mathrm{c}$.

We can furnish the California varieties at $50 \mathrm{c}$ for 2 year vines.

\section{BLACKBERRIES}

50c per dozen; $\$ 3.50$ per 100 .

Dallas-This is the most popular Blackberry in the state. A native Texan, strong grower, heavy bearer, and fine quality.

McDonald-A very fine early berry, strong grower 
and fine quality. It must be planted with other berries to be successful-Austin Mays, Dallas or Robinson.

Robinson-This is a very vigorous, upright-growing berry, of large size and splendid quality; was introduced by Willard Robinson of Cisco. It ranks high among berries.

\section{DEWBERRIES}

50c per dozen; $\$ 3.50$ per 100 .

Rogers-This is a native of South Texas and the earliest berry on the market. A very strong grower, large berry and fine quality. Ripens with the wild berry.

Austin Mays-Originated near Pilot Point, Texas, and successful all over the state. A very large berry and very prolific. The main crop dewberry of the state.

Blackberries and Dewberries are the quickest and surest market fruits in the South. We can make very attractive prices on thousand lots.

\section{THE HAUPT BERRY}

Introduced by F. T. Ramsey of Austin. and below we give his description: "The late Colonel Haupt, of Hays County, spent much time and money in collecting dewberries and blackberries. He got one (probably from Wharton County) that eclipses every. thing. It is certainly the most valuable variety of fruit of any kind. A few years ago we paid a fancy price for all the plants he would spare. We found them robust growers, never turning yellow, ripening early in April and May, and best of all, they never have a faulty or poorly filled berry. They are of good size and of the very highest quality; they keep for a long time after turning black. The plants are very productive."

It has those characteristics that denote it as a cross between a dewberry and a blackberry. There are two or more slightly different strains mixed. The "Haupt" is an evergreen like a southern dewberry, so can be planted in the summer as we have found out.

20 e each; $\$ 1.50$ per dozen; $\$ 6.00$ per 100 .

\section{HIMALAYA BERRY}

Quite a remarkable berry that has been advertised extensively; under favorable conditions it makes 15 to 30 feet growth in a season, and is best on low trees or some support. The fruit is about the same as a blackberry and parties who have grown it claim it to be a wonderful bearer. It seems really to be a success.

25c each. Per dozen $\$ 2.50$.

\section{STRAWBERRIES}

Klondike-One of the best known- $\$ 1.50$ per 100 ; 50 at 100 rates.

Everbearing Strawberries-Is claimed to bear nearly all summer. We have not fully tested them; $\$ 3.00$ per 100.

\section{ASPARAGUS ROOTS} 100.

Three leading varieties-50c per dozen; $\$ 2.50$ per

\section{RHUBARB}

Crimson Winter-Very fine variety from California. 25 c each; $\$ 2.60$ per dozen. 


\section{PECANS}

The Pecan is rapidly growing in popularity, both as a shade and commercial orchard tree. We are growing the leading varietics and hearitly recommend them to everyone who has a piece of land on which to plant one.

\section{Prices}

1 to $2 \mathrm{ft}$.

Each Per 12 Per 100

2 to $3 \mathrm{ft}$. $75 \mathrm{c}$

$\$ 7.50$ $\$ 60.00$

1.00

3 to $4 \mathrm{ft}$.

4 to $5 \mathrm{ft}$.

1.50

10.00

75.00

6 to $7 \mathrm{ft}$. 2.50

15.00

20.00

Varieties: Stuart, Schley, Van Deman, Delmas, Holbert and others. Write for special rates on large lots.

\section{Ornamental Department}

\section{SHRUBS}

Good 1 year $40 \mathrm{c}$ each; $\$ 4.00$ per Dozen.

2 and 3 year $75 \mathrm{c}$ each; $\$ 7.50$ per Dozen.

Althea-Assorted colors; bloom all summer.

Crape Myrtle-Assorted colors; best of bloomers.

Syringia or Mock Orange.

Lilac-Persian purple; best for South.

Deutzia.

Flowering Willow-Fine grower; blooms all season. Hardy Salvia-Evergrcen and blooms all summer.

Poinciana or Bird of Paradisc.

Butterfly Bush-Very fine, 50c, $75 \mathrm{c}$ and $\$ 1.00$ sizes.

Mallow Marvels, or Hardy Hibiscus; 1 yr. $25 \mathrm{c}$ each.

Bush Honeysuckle-IVinter blooming.

Flowering Pomegranate-White and red.

Siberian Pea Tree-Yellow, full shaped flowers.

Cydonia Japonica, or Burning Bush-blooms before leaves start.

Tamarix-Salt Cedar; best pink flowering variety. Red Bud-50c and $\$ 1.00$ sizes.

Spirea Van Houti-Bridal Wreath; best of all Spi. reas.

Forsythia or Golden Bells.

Coral Berry.

Vitex or Spice Bush-Grows to small tree; blooms all summer.

Wegelia-Best pink variety, $75 \mathrm{c}$.

Prunus Pissardi (Purple Leaf Plum)-Excellent for eolor effect owing to its dark red foliage and black bark. Gives an autumn effect and is very attractive for border bankings and landscape groups.

Prices

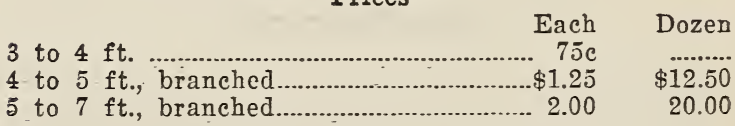

\section{HARDY CIIMBING VINES}

Honeysuckle-Eviergreen; 2 year 50c; 1 year 35̃c.

Trumpet Creeper-25c.

Bcston Ivy-Clings to wall or posts; 2 year 35c; also in larger sizes.

Red Coral Honeysuckle-50 and $75 \mathrm{c}$.

Kudzu Vine-Most rapid of all growers, 35c.

Wistaria-Purnle, 2 years, $50 \mathrm{c}$ and $75 \mathrm{c}$.

Wistaria-White, strong, 2 year $50 \mathrm{c}$. 
Queen's Wreath-Nothing finer; 2 year, strong, 50e; extra heavy $75 \mathrm{c}$.

Clematis Paneculatta-Old favorite; $35 \mathrm{c}$ and $50 \mathrm{c}$.

Trailing Vinca-Evergreen; for shady places or banks, $15 \mathrm{c} ; \$ 1.50$ per dozen.

English Ivy-True evergreen, 25c and 35c.

\section{ORNAMENTAL GRASSES}

Arundo Dona (Ribbon Grass) 35c.

Eulalia Japonica Zebrina-50e; heavy clumps $\$ 1.00$ and $\$ 1.50$.

Pampas Grass-Finest of all grasses, 50c; large clumps $\$ 1.00$ to $\$ 2.50$.

Iemon Grass-Strong lemon flavor, 50c. .

Golden Rod-Tall spikes of yellow flowers in fall; 15 c, $\$ 1.00$ a dozen.

Latana-Low bush, dark green foliage, handsome flowers. Very hardy; stands drouth. Extremely attractive; blooms all summer. Several varieties, $35 \mathrm{c}$.

Helianthus Maximilianii-Large yellow flowers with yellow centers; stems 5 to 7 feet. Blooms in fall. Most effective in all plantings. Takes places of Gol: den Glow in the South. 35 cents.

Flowering Peach-A real peach trec, covered in spring with very large double flowers like little roses. Very fine; double red, double white.

\section{HEDGE PLANTS}

\section{California Privet-}

12 to 18 in., heavy rooted, $\$ 5.00$ per 100 .

18 to 24 in., heavy rooted, $\$ 7.50$ per 100 .

Larger sizes at $\$ 10.00$ and $\$ 15.00$ per 100 .

Amoor River Privet-

18 to 24 in., $\$ 10.00$ per 100 .

2 to $3 \mathrm{ft}$., $\$ 15.00$ per 100 .

Larger grades, $\$ 20.00$ and $\$ 25.00$ per 100 .

Chinese Arborvitae-12 to 15 inches; each $25 \mathrm{c}$; per $100 \$ 20.00$.

Lilac, Althea, Crape Myrtle and Roses are also used as hedges. Will be glad to make prices on any of above.

\section{CANNAS}

A fine assortment of best red, yellow, salmon and spotted varieties; $15 \mathrm{c}$ each or $\$ 1.50$ per dozen.

Mrs. A. Conard, City of Portland, Rosea Gigantia and other fine Pinks, 25e each; $\$ 2.50$ per dozen.

Mexican Tuberose-Best grown, 50c per dozen; $\$ 4.00$ per 100 .

Gladiolas-Best mixed, 75c per dozen.

Milk and Wine, or Angel Lily-25e each, $\$ 2.50$ per dozen.

Iris-Best pure white, dark purple, yellow and lavender-pink varieties; $15 \mathrm{c}$ each; $\$ 1.50$ fer dozen.

Amaryllis Johnsonii-Best red; $50 \mathrm{c}$ and $\$ 1.00$ each.

Shasta Daisy-50e per dozen, $\$ 3.50$ per 100 .

Violets-Best blooming sorts; 35e per dozen, $\$ 3.00$ per 100.

Hollyhocks-Two-year plants, assorted colors; 25c each; $\$ 2.50$ per dozen.

Banana Plants-50e to $\$ 1.50$.

Calladium-35c, $50 \mathrm{c}$ and $75 \mathrm{c}$.

Santolina-An evergreen border plant that is very fine for bordering beds or walks. Grayish green and aromatic like Rosemary; small plants $\$ 15.00$ per 100 :

\section{EVERGREENS}

Evergreens have just begun to receive the attention they deserve. The idea that because they have beed 
used in cemeteries they are not in place in home planting is rapidly passing and our foremost landscape men use all classes of evergreen in their work. We of the South have made the mistake of trying to grow varieties that are successful North and East but are not adapted to the South. Also the mistake of planting evergreens bare rooted has resulted in many serious failures. Most evergreens should be balled and burlapped and this if well done will practically guarantee the growth of plants moved in this manner. Evergreens are divided into two general classes, namely the Broadleafed and Coniferous, and by combining the two classes and using flowering shrubs to fill in spaces between, wonderfully beautiful effects are secured and continuing through the entire year.

\section{Coniferous Evergreens}

Arborvitae Compacta or Golden "Thuya Compacta" -Broad, low growing; one of the very best for the South.

15 to 18 inches, balled and burlapped....................\$1.50

18 to 24 inches, balled and burlapped........................ 2.50

24 to 30 inches, balled and burlapped..................... 3.50

Pyramidal Arborvitae (Thuya Pyramidalis Bakus) -This is the true compact Golden variety, but grows in more pyramidal shape.

15 to 18 inches, balled and burlapped....................\$1.50

18 to 24 inches, balled and burlapped...................... 2.00

2 to $2 \frac{1}{2} \mathrm{ft}$, balled and burlapped............................ 3.00

$21 / 2$ to $3 \mathrm{ft}$., balled and burlapped.............................. 4.00

3 to $4 \mathrm{ft}$., balled and burlapped................................... 5.00

Rosedale Arborvitae (Thuya Rosedale)-This is of Southern origin and is one of the prettiest of our evergreens.

15 to 18 inches, balled.............................................. $\$ 1.00$

18 to 24 inches, balled................................................. 2.00

24 to 30 inches, balled................................................. 3.00

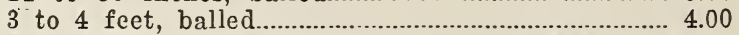

Extra large plants...................................... $\$ 7.50$ to $\$ 10.0$

Chinese Arborvitae (Biota Orientalis) - This is a rapid growing Arborvitae of rather open growth and requires pruning to make a compact plant. Is fine for mixed plantings and hedges.

12 to 15 inches, bare rooted................................... 35c

15 to 18 inches, bare rooted................................... 50 c

18 to 24 icnhes, bare rooted................................. $75 \mathrm{c}$

2 to 3 feet, bare rooted........................................ $\$ 100$

3 to 4 feet, bare rooted.......................................... 2.00

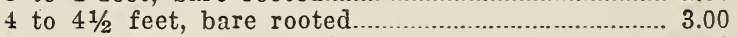

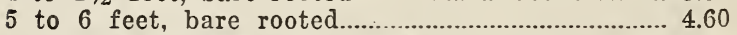

Arizona Cypress (Cupressus Arizonica))-This is one of the prettiest evergreens in the South. It is a beautiful gray green in color and makes a large, handsome plant; a rapid grower.

8 to 12 inches, in pots.................................... $75 \mathrm{c}$

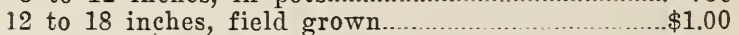

18 to 24 inches, field grown …….................... 2.00

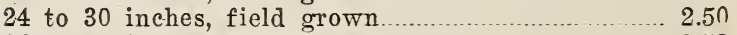

36 to 42 inches, field grown...................................... 3.50

Large size specimens $\$ 10.00, \$ 15.00$ and $\$ 25.00$.

Italian Cypress (Cupressus Sempervirens)-Tall, slender, columnar shapes; one of the finest of our evergreens. Verv graceful and effective.

8 to 12 inches, from pots................................. 75 c

12 to 18 inches, from pots.................................. $\$ 1.00$

18 inches to $2 \mathrm{ft}$., from pots................................ 150

$21 \%$ feet. field grown

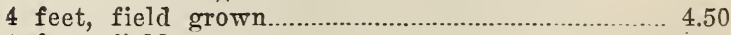

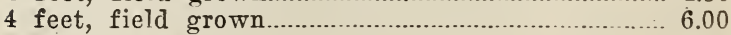

5 feet, field grown 
Horizontal Cypress (C. Horizontalis)-Somewhat like above, but branches run out horizontally instead of running up like the pyramidal.

18 to 24 inches.

2 feet to 30 inches.

3 to 4 feet 2.50

Red Cedar (Juniperus Virginiana)-This is a beautiful evergreen, fine for mixed planting or single specimens. We have both the Southern and Platte River types.

18 to 24 inches, balled and burlapped

24 to 30 inches, balled and burlapped....................... 1.50

3 to 4 feet, balled and burlapped............................. 2.25

4 to 5 feet, balled and burlapped............................... 3.50

5 to 6 feet, balled and burlapped.

Extra large sizes, $\$ 7.00$ to $\$ 15.00$ each.

Himalaya Pine (Cedrus Deodara)-This is considered the grandest of all the conifers for the South. It takes the place of the blue spruce in the North.

18 inches to 2 feet, in pots................................ $\$ 2.00$ $2 \frac{1}{2}$ to 3 feet, balled and burlapped......................... 5.00

We have larger plants at $\$ 7.00, \$ 10.00, \$ 15.00$ and $\$ 20.00$. These are very scarce at present.

\section{BROAD LEAVED EVERGREENS}

Abilia Grandiflora-A splendid evergreen that blooms all summer. Covered through the season with small white pink-tinted blooms. A very satisfactory plant.

12 to 18 inches, $50 \mathrm{c}$; larger sizes $\$ 1.00, \$ 1.50$ and $\$ 2.50$ Can be planted bare-rooted by cutting back well. Larger plants balled and burlapped.

Buxus (Boxwood)-Fine for tubs, urns, boxes, etc.; $50 \mathrm{c}, \$ 1.00, \$ 2.50, \$ 5.00$ and $\$ 10.00$ sizes-all balled.

Cape Jasmine-This is one of the most beautiful plants in the South. Rich, dark green all the year and beautiful waxy white flowers in spring.

Euonymus Japonicus-This is a very useful evergreen for almost any location. Has thick heavy green leaves that hold their color winter and summer. Can be pruned to any shape and grows under adverse conditions better than most any of our evergreens. Fine for low hedges; $15 \mathrm{c}, 25 \mathrm{c}, 50 \mathrm{c}, \$ 1.00$ and up to $\$ 4.00$ sizes.

Dwarf Euonymus (E. Pulchellus)-This is a dwarf variety of the above, having very fine leaves and never grows higher than a foot to 15 inches. Very fine for low borders. One year plants $20 \mathrm{e}$ each, $\$ 15.00$ per hundred. Strong, 2 year, 50c.

Climbing Euonymus (E. Radicans) -Not a decided climber, but more of a pillar plant. Dark rich evergreen.

Euonymus Compactus-A new variety with small, box-like foliage that grows in compact cone shape, without pruning. Fine for hoxes and tubs. Plants $50 \mathrm{c}$ to $\$ 2.50$.

Golden Euonymus (E. Aurea)-A variety with leaves heavily marked with rich golden color. 12 to 18 in., $\$ 1.00$; larger sizes $\$ 1.50$ and $\$ 2.50$.

Ligustrum. Japonicum-Large rich dark green foliage, fine for snecimens, screens, large clumps, etc; tall growing. Makes a handsome shade tree when cut to one stem. One year plants 18 to 24 in., $35 \mathrm{c} ; 2$ to $3 \mathrm{ft}$. $50 \mathrm{c} ; 4 \mathrm{ft}$. $75 \mathrm{c} ; 4$ to $5 \mathrm{ft}$. $\$ 1.50$. Small hedge size $15 \mathrm{c}$ to $25 \mathrm{e}$.

Ligustrum Japonicum Macrophyllum (balled and burlapned)-A very large leaved sort that is quite rare. Much larger and richer foliage than the regu- 
lar Ligustrum. Grafted plants, 3 to $4 \mathrm{ft} ., \$ 2.00 ; 4$ to 5 ft., $\$ 4.00$.

Ligustrum Japonicum (Marguata Aureum-balled and burlapped)-Vcry much the same type as above, but with leaves nearly covered with yellow. Grafted plants, 18 to 24 inches, $\$ 1.50 ; 2$ to $3 \mathrm{ft}$., $\$ 2.50$.

Ligustrum Lucidum (or Wax Ligustrum)-This we consider by far the finest of all the Ligustrums; is not so tall, but more spreading in growth. Leaves are a rich, dark waxy green and holds its color throughout the winter. In spring it is covered with large heads of white flowers like a white lilac. Much prettier than any white lilac in the South. For foundation plantings, clump or specimens, it is unsurpassed.

12 to 15 inches, balled and burlapped...................... $\$ 1.00$

15 to 18 inches, balled and burlapped........................ 1.50

18 to 24 inches, balled and burlapped.......................... 2.00

24 to 30 inches, balled and burlapped....................... 3.50

30 to 36 inches, balled and burlapped.......................... 4.50

Iigustrum Quoihi (Chinese Ligustrum)-A rapid growing variety with very small fine leaves that blooms througle the fall; very scarce.

12 to 18 in., balled and burlapped.

18 to 24 in balled and burlapped

2 to $3 \mathrm{ft}$.

3 to $4 \mathrm{ft}$., balled and burlapped................................ 3.50

Southern Laurel (or Wild Peach)-One of the finest evergreens. Native to certain parts of the state. $11 / 2$ to 2 ft. $\$ 1.50 ; 2$ to 3 ft. $\$ 2.50 ; 3$ to $41 / 2$ ft. $\$ 4.50$. Balled and burlapped.

Ligustrum Amurense-Fine, graceful foliage, rapid grower. 2 to $3 \mathrm{ft} .25 \mathrm{c} ; 3$ to $4 \mathrm{ft} .50 \mathrm{c} ; 4$ to $6 \mathrm{ft} . \$ 1.00$. Bare rooted.

Nandina Domestica-Beautiful evergreen with rich bronze foliage through the winter. Only $\$ 3.50$ and $\$ 5.00$ grades.

Photima-This is a large leafed evergreen with parts of foliage changing to red in winter; quite attractive. Only in $\$ 3.50$ and $\$ 5.00$ grades.

Pyracantha-Evergreen Thorn. Only in $\$ 2.00$ sizes.

Magnolia Grandiflora-Grandest of all Southern evergreen trees; too well known to need description. 18 to 24 inches $\$ 1.25 ; 2$ to 3 ft. $\$ 2.00 ; 3$ to $4 \mathrm{ft} \$ 3.00$.

Rosemary-Old favorite aromatic shrub, with gray green foliage; 12 to 18 in. $75 \mathrm{c}$. Extra sized plants, balled and burlapped, $\$ 1.50$.

\section{ROSES}

The Rose is easily the most popular of all flowers and will give more returns for the outlay than any plant we know of. But certain conditions must be met if they are even fairly successful. They must have good soil, and all of it to themselves-and plenty of sunlight. Never mix them with shrubs or grow them in beds with annuals, or plant near large trees. If you cannot find a good place in the yard, give them a side or corner of the garden. The varieties listed are fully tested in the South and there is not a doubtful sort among them. You will be safe in planting them in twos, sixes or dozens of a variety. Prune back severelv when planting and plant about two inches deeper than where they are budded.

American Beauty-Great favorite; bright red. 2 yr. plants $50 \mathrm{c}$ each; $\$ 5.00$ per dozen.

Etoile de France-Rich dark red. Extra large plants $75 \mathrm{c}$ each; $\$ 7.50$ per dozen.

Edward Mawley-Dark red.

Felen:Gould-Bright red, old favorite. 
Frances Scott Key-Very fine new red; large and full.

Red Radiance-Bright Red; excellent.

Kaiserin Augusta Victoria-Nothing better as a white.

White American Beauty-Very large and fine; blooms spring and fall.

White Cochet-An improvement on the Bride and with the K. A. Victoria are the best whites we know.

Pink La France-Old favorite; well known.

Pink Radiance-Strong grower.

Mad. Caroline Testout-Shell pink.

Pink Cochet-Beautiful long buds.

J. I. Mock-Very large, lond buds; fine grower.

Paul Neyron-The largest pink Rose; very fine; fall and spring.

Malmaison-Flesh pink, old variety; fine bloomer.

Mrs. Abel Chutney-Very fine pink.

Columbia-New pink, very fine.

Ia Detroit-Fine pink.

Lady Hillingdon-Very fine yellow.

Sunburst-Yellowish bronze.

Soleil de Or-Rich yellow.

Luxemberg-Pink and yellow; very fine, $75 \mathrm{c}$.

Los Angeles-Very unusual color, pink and gold, $75 \mathrm{c}$.

Ophelia-Salmon pink; new variety, $75 \mathrm{c}$.

Baby Rambler-Dwarf, red, ever bloomer.

Orleans-Like above, but with white center.

Premier.

\section{CLIMBERS}

Dorothy Perkins-Pink, well known climber; $\$ 2.50$ per dozen.

Dorothy Perkins-Red, well known climber; $\$ 2.50$ per dozen.

Climbing K. A. Victoria-Like bush; best.

Ia Marque-White Climber.

Climbing White Cochet-Very fine, new white climber, $75 \mathrm{c}$.

M. Neil-Finest of yellow elimbers; large grafted plants, $75 \mathrm{c}$.

Climbing Meteor-Of the best red monthly climbers. Climbing Testout.

\section{SHADE TREES}

All nursery grown, well rooted, nice shaped. Great numbers are being used for street planting, home grounds, parks, etc.

\section{Elm-American White}

\begin{tabular}{|c|c|}
\hline & Each \\
\hline to 5 feet & $\ldots \ldots \ldots$ \\
\hline fee & 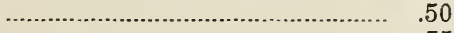 \\
\hline to $8 \mathrm{f}$ & .75 \\
\hline
\end{tabular}

Sycamore

4 to 5 feet

$\$ .35-\$ 3.50$

5 to 6 feet

6 to 8 feet

7.50

8 to 10 feet

10.50

10 to 12 feet

15.00

Black Locust

5 to 6 feet 
Umbrella China

Small Plants. $35 \mathrm{c} \quad 4$ to 5 feet $.75 \mathrm{c}$ Larger grades $\$ 1.00$ and $\$ 1.50$.

\section{Lombardy Poplar}

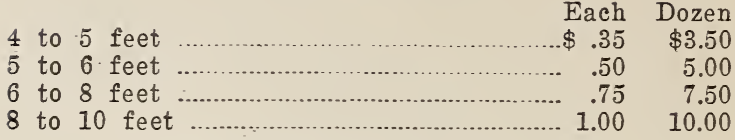

Carolina Poplar-Same price as above. Chinese Poplar

A new variety introduced from China. Same shape as Lombardy, but quite different leaf. A fence tree. Each Dozen

3 to 4 feet $\$ .35 \$ 3.50$

4 to 5 feet

5.00

5 to 6 feet
6 to 8 feet

7.50

.75

10.00

\section{Japan Varush}

A very fine ornamental and shade tree. Perfectly hardy and good grower.
4 to $5 \mathrm{ft}$. $\$ 1.00$
5 to $6 \mathrm{ft.} \$ 1.50$
6 to $8 \mathrm{ft} . \$ 2.00$

Catalpa

\begin{tabular}{rrrrr} 
& \multicolumn{2}{c}{ Catalpa } & Each & Dozen \\
4 to 6 feet & & $\$ 50$ & $\$ 5.00$ \\
6 to 8 feet & & .75 & 7.50
\end{tabular}

\section{Weeping Willow}

$\begin{array}{rrrrr}3 & \text { to } 5 \text { feet } & \text { Each } & \text { Dozen } \\ 5 & \text { to } 6 \text { feet } & & .50 & \$ 500 \\ 6 & \text { to } 8 \text { feet } & & .75 & 7.50 \\ & & & \end{array}$

\section{Red Bud}

$\tilde{\partial} 0 \mathrm{c}$ to $\$ 1.50$ each.

\section{Red Oaks}

The Oaks are one of the finest.

4 to 5 feet

Each Dozen

6 to 8 feet

$\begin{array}{rr}.50 & \$ 5.00 \\ 1.00 & 10.00\end{array}$

\section{Cork Bark Elm}

The elm that produces the cork used in commerce. 6 to 8 feet.................. $\$ 1.008$ to 10 feet. $\$ 1.50$

\section{Russian Mulberry}

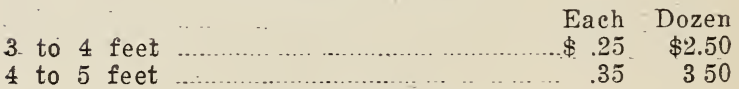

\section{Fruiting Mulberry}

4 to 5 feet

6 to 8 feet. $75 c$

\section{Pecans, Native}

The Pecan is one of the very finest of shade trees and ranks with the oak for permanent planting, and while we believe it best to plant the grafted thinshell varieties, any kind of pecan is well worth planting. We can supnly seedling trees as follows:

12 to 18 in., 2 or 3 year roots................................. $30 \mathrm{c}$

18 in. to $2 \mathrm{ft}$., 


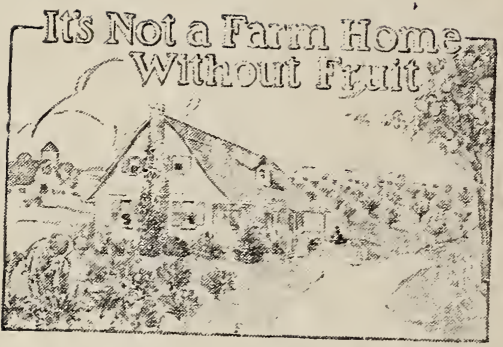

MEMBER OF THE

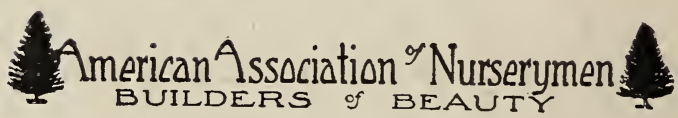

